\title{
The Russian Factor in Turkey's Georgian Policy after the Russian- Georgian War (August 2008)
}

\author{
Murad Asadov \\ Azerbaijan, Baku State University, International Relations and Economic Faculty, Ph. D,
}

\begin{abstract}
Formation of new states in the South Caucasus and Central Asia after the collapse of the Soviet Union raised to have relations with the Turkic peoples of Central Asia first in the history of the Republic for Turkey. Foreign policy the Caucasus continues to evolve in its foreign policy strategy. A force associated with this well-intentioned policy, which is adjacent to the Laki region, is always offered. Whenever Turkey wants to enter the Caucasus, it will not be adversely affected by other countries. With the collapse of the Soviet Union in the 1990s, Russia's influence in the region was weak. The nickname was temporary. At the beginning of the 21st century, Vladimir Putin received a well-developed document with the credibility of Putin.

Turkey's north-east neighbour Georgia is not a very big country, it has a particular importance of the geostrategic position not only in the Caucasus region but also in Turkey. Especially, the location of Georgia in the centre of the transport and trade routes to the Caucasus and Central Asia increases its geostrategic status more. The main positive turning point in the development of Georgia-Turkey relations happened with the realization of oil and natural gas pipelines to run Caspian oil through Tbilisi to Turkey and from there to the West.

This article will explore the Turkish-Russian relations of the late twentieth and early twenty first century and the Russian factor in Turkey's South Caucasus policy following the August 2008 events.
\end{abstract}

Keywords: USSR, South Caucasus, Turkey, Georgia, Russia, Middle East, Black Sea, NATO

Introduction. Since the establishment of the Turkey Republic(T.R), the emergence of M.K Ataturk is to restore international peace and harmonize its foreign policy with the principle of "Peace in the Land, Peace in the World". But after Mustafa Kemal Ataturk, this policy is very passive. Turgut Ozal, the former president of T.R, is evolving into foreign relations with the impact of globalization on the world, and foreign relations embarking on a new foreign policy course. During this period, develop it foreign relations, as well as establish and coordinate peace in the region.

The Caucasus is a region of Central Asia's Black Sea region and an influential geopolitics of Russia, Turkey and Iran, creating faith in Anatolia and Europe. The Caucasus is a unique region in the newly created world order after the Cold War. It is in the middle of Turkey's three best crisis crises. The connection of these areas of experience (Caucasus and the Middle East) with energy resources and the service of the interest of the world countries, as well as their competitiveness. This situation is a little harder to respond to the health of the region. It is connected with the Caucasus geography worldwide and is located in the same geography as Turkey. Thus, the terms "Asia Minor" and "Asia Minor", called Anatolia and the Caucasus, are not mentioned. This geographical proximity also has a significant impact on the historical, demographic, cultural and political development of the region. Therefore, development related to the Caucasus region requires better integration into the region after the collapse of the USSR(Sawash, 2002, p. 4-5).

After the cold war,Turkey that seriously affected by the power vacuum in the international arena incurred these events without any preparation and faced with the difficulty in establishing foreign policy. One of the main features in Turkey foreign policy was its "Western tendency".According to some politicians, this situation created ambiguity in Turkey's foreign policy and would replace EU variant with South Caucasus one.However, first, it must be stated that "Turkey's Caucasus variant as an alternative to the West" is not 
true. Because Turkey does not have any chance to accept these two compositions separately due to its geopolitical position.First emerging discussions about the direction of Turkish foreign policy caused a deadlock as they were based on the east and west discrimination. Because Turkey must have relations both with the east and west. Therefore, Turkey should perform progress in both areas understanding its role of complement, not an alternative to EU in South Caucasus policy. Certain geopolitical and security relations of Turkish foreign policy should be considered the same as economic relations.Turkish foreign policy should be established by not romance but a real outlook. In this context, Turkey should pursue a decisive policy toward the South Caucasus countries and its existence should be felt. From the other side, the Republic of Turkey representing Turkish originated population living in the regional countries should strengthen the support to the region and become attractive to it.

\section{The role of the South Caucasus in Turkish-Russian political relations}

Relations between Turkey and Russia influenced their shared neighbourhood, the Caucasus. From the 18th century up until their demise, the Russian and Ottoman Empires vied for influence and territorial control in the region. During the Cold War, Turkey's Western-oriented forieng policy largely ignore the Caucasus, then part of the Soviet Union. It was only after the collapse of the USSR that Turkey sought a more prominent role in the region.

After the collapse of the USSR, Turkey was to revise its foreign policy to find a new ally to defend the interests of Turkey on the international platform as a result of new friendly relations between the East and the West Bloc. Turkey is a country with both a strategic importance and a stable structure with a democratic, secular and free market economy. When the winds of independence in the Caucasus were blown, it would be appropriate to divide Turkey's foreign policy into two priorities; the first was to advance Russia's return to the South Caucasus, to support the regional states' independence and territorial integrity, and the second was to transport energy resources from the Caspian Basin to Western markets(Bal, 2006, p. 458 ).

The Caucasus policy of Russia in 1991-1993 has been very passive. After 1994, Russia was interested in its surroundings. The Central Asian and Caucasus regions were expected to be close. Russia's foreign policy strategy has opened its doors to the use of doctoral studies in the Middle East. On 19-20 November 1999, the OSCE Istanbul Summit was re-discussed and the arms restriction was revised. Zbigniew Bzezinski called Russia an "unexpected country" in his "The Great Chessboard"(Brzezinski, United States, p. 128). In general, it would be wrong to diminish Russia's role in world politics after the collapse of the Soviet Union. The result was that some of the Alliance countries, including Georgia, were conducting erroneous geopolitical courses. After the collapse of the USSR, the leadership of Moscow began to withdraw from the former Soviet property. But the geography of withdrawal was a matter of debate. Georgia was also supported by the North Caucasus Military Department as a country providing modern weapons to Russia in the South Caucasus. The policy of Georgian President Z. Gamsakhurdia was to reduce Russia's influence and move closer to the West. Georgia's first step on this path was Russia's refusal to join the Commonwealth of Independent States (CIS). However, Russia did not want to lose its influence in the Black Sea and the Caucasus, and therefore supported ethnic groups in Georgia by creating internal conflicts and forcing the government to resign. But the last Soviet foreign minister who came to power did not act as Russia thought(academicperspective. com).

Georgia is the only country in the Caucasus to have access to the Black Sea. Georgia is also the shortest road connecting Central Asia and the Caucasus to the West. For this reason, it would be more appropriate to say that Georgia is a very important country for Turkey as well as for Western countries(www. academicperspective.com).

Turkey should never forget that Caucasus and Georgia situated on the Silk Road are an open door to Central Asia. Turkey should always continue to appreciate Georgia as an absolute strategical partner. Ambassador of the Republic of Georgia in Ankara, Grigol Mgaloblishvili told: "There is a saying in Georgia; A neighbor living nearby is better than a relative far away. Turkey is our nearby neighbor and very close brother country. Therefore, we are in a position of seeing each other as a brother easily" (International Turkey-Asia congress; 2006.81).

The foundation of the relations between Georgia and Turkey lay the signed contracts among two countries. The first contract was signed on 30 July 1992 during the first official visit of Suleyman Demirel to Georgia. 
Shevardnadze was pleased by Demirel's visit and meet him with the words "You are the first delegate in the Prime Minister level coming to my country,welcome". In front of this sincerity, Demirel answered expressing that Georgia is "a friend and brother" country. Relations started with sincerity between two countries developed rapidly and caused the creation of the partnership in different fields (Sahalho newspaper, 22-28 Jule 1997). Energy is the main reason to close Turkey and Georgia. Georgia is the route of Baku-Tbilisi-Ceyhan oil pipeline and Baku-Tbilisi-Erzurum gas pipeline.It would be wrong if we assess these pipelines only from the economic perspective bringing significant economic benefits to Turkey. Because not only economic but also the strategic measure of these pipelines are very important. Except economic profit targets, Turkey has varied political purposes in transport project like to expand its importance in Transcaucasia, to become a bridge for Europe that supports it with energy and to prevent Russia's influence in the region (Demirag, 2005: 127-128).

The United States has also been involved in the struggle for greater power in the region between Turkey and Russia since the middle 1990s. Since that time, Turkey has acted with the United States in most of the regional events. The imbalance of power between Russia and Turkey, especially in the military, has forced the region to act alongside the United States.

One of the most important factors influencing Turkey-Russia relations and the policy pursued by both countries in Central Asia and the Caucasus is the West. Since the fall of the USSR, Russia has pursued a policy that is compatible with the US and Europe, but since 1993 it has begun to look for new allies in Asia, with a focus on maintaining good relations with Europe and the United States. Domestic tensions during this period caused delays in Russia's foreign policy, which had a significant impact on Central Asia and the Caucasus. Russia has claimed that the territory of the former USSR is a vital area of economic and security interest in the Middle East, and wants to control the events there(Alkan, September 2008).

Today, Turkey and Georgia describe their mutual relationship as a strategic partnership; Turkey's role in the economic sphere is accurately described as that of a "merchant hegemon" (a term coined by Caucasus expert Michael Cecire). Ever since Georgia's Rose Revalation in 2003. Turkey has been its leading trade partner and major investor, playing an important role in softening the impact of the 2005 Russian trade embargo, A free trade agreement between Turkey and Georgia came into force in 2008(Weiss, Zabanova. December 2016. p 2).

Thus, Turkey, which has strong trade and cultural ties with the Caucasus, will not be able to watch the events. As the policy pursued during the Russian-Georgian conflict, and later on the initiative of the Caucasus Stability and Cooperation Platform, Turkey has once again demonstrated its intention to pursue an active and peaceful foreign policy in the region. Rivalry persists between Russia and Turkey in their shared neighbourhood of the South Caucasus. But Moscow-Ankara relations have warmed overall. Building on their wider rapprochement, the two powers can work together to tamp down flare-ups of regional conflicts.

\section{Georgian factor in Turkish-Russian relations}

Former Prime Minister of TurkeyAhmet Davutoglu's strategic depth doctine, which calls for an an activist engagement with all regional systems in Turkey's neighbourhood. Although Russia recognized Georgia's independence in mid-1992, it opened its embassy in October 1993. According to many researchers, Russia has sought to strengthen its control in Georgia by supporting minority problems. One of the reasons for this was Russia's claim to the former Soviet Union that it was always trying to take advantage of ethnic conflicts in those areas.

Russia was expected to announce the concept of official foreign policy after the collapse of the Soviet Union. But as a result of the political events that followed the collapse of the USSR, the approaches to Central Asia and the Caucasus differed. According to the Doctrine of the Near Circle, the settlement of conflicts around Russia and the protection of Russian population and human rights in the region, the deployment of Russian "peacekeepers" to neighboring countries within the framework of security with the CIS countries, thus creating a security zone near Russia. By mid-1992, Russia had established diplomatic relations with all new independent states, except Ukraine and Georgia, and signed bilateral friendship and cooperation agreements, based on the principles of sovereignty, territorial integrity and non-interference in internal affairs. Georgia is the country with the most problems with Russia. To the Russian-Georgian 
relations have been affected by events like Abkhazia and South Ossetia, oil pipelines, and the second Chechen war.

Turkey, however, was watching whether Russia's policy in the Caucasus would have a positive or negative impact on itself. In this case, as in the past, the future of the region has become dependent on Russia. Russia was determined not to pull its troops out of Georgia, implying its strategic goals. In this case, the Georgian army was trying to seize the former Soviet military bases in the area. The United States played an important role in the establishment of the Georgian army. Georgia has re-established its military using the US-led Foreign Military Financing and International Military Training and Training Programs. Under this program, in 2001, 10 UHIH helicopters were purchased from the United States(Shen, 2008, p 30).

Russia's support for the conflicts in the South Caucasus would not be untrue. Turkey's efforts to boost its presence in the region in 1993-1994 were closely followed by Turkey. Concerned by Russia's actions, Turkey held discussions with the United States on this issue. On March 11, 1994, Assistant Secretary of State for Foreign Affairs Toby Qati met with Unan, US State Department Counselor. After the talks in Moscow, the main topic of Qatari's talks in Turkey was Russia. US Foreign Ministry Undersecretary Unan said Russia systematically intervenes in the Balkans, Central Asia and the Caucasus, opposes Azerbaijan in the conflict between Azerbaijan and Armenia and seeks to enhance its military and political activities over Georgia and Armenia. But even though the US condemned Russia's policies, it did not take any action. The US did not want to engage in a new military conflict with Russia.

Russia has planned to use more military force to change its influence mechanism in the region in order to reduce the success of Turkey's successful policies in the region. For this reason, he was trying to pursue a foreign policy that would hinder Turkey's development of relations with the countries of the region.

Although Turkey does not have much influence in the region, a number of events in its territory and internationally have affected its penetration into the region. The Caucasus is important for Turkey's geopolitical interests for three reasons; The region's gateway to Central Asia, the Caucasus is a secure region between Russia and Turkey, and is of great importance in terms of transport to the Caspian energy resources in the region.

While Georgia, Armenia, and Azerbaijan are new states in the Caucasus policy, Russia cannot rely on its vast military and economic power to control the region as it did during the Soviet era. Georgia's defiance of Russia has caused ethnic problems here again. The foreign policy of the Tbilisi authorities was to integrate with the West by establishing a balanced relationship with Russia. Because it is impossible for Georgia to fight Russia alone. This is why Turkey, in particular, needs regional and global friendly countries. Turkey has always viewed Georgia as an "ally country", with constant support of its neighbor. Even after the Russian-Georgian conflict, Georgian Defense Minister Irakli Alasania praised the relations between the two neighboring countries(www.turkishpolicy.com). In his view, Russia's policy towards Georgia can never affect relations between the two neighboring countries. He even praised Turkey's support for Georgia during the conflict. He said Turkey would play a special role in the settlement of the conflict in the future and expressed satisfaction with the positive development of relations between the two countries.

After the collapse of the USSR, with the independence of Georgia and Ukraine, the threat to the Black Sea and the Straits has been eliminated. The emergence of problems with the new states around the Black Sea played a key role in their approach to Turkey. Although Turkey, the largest coastal country in the world, provides diplomatic advantage, it has not been prepared enough to integrate it. Because Turkey did not achieve any result in Caucasian politics and the Azerbaijan-Armenia conflict slowed down its regional policy. For this reason, Turkey, despite its geographical proximity and strategic importance, was not sufficiently interested in the events in South Ossetia and Abkhazia, as it could not be concerned with Georgia. In fact, both the economic situation and the events at that time did not allow Turkey to integrate into the Caucasus. For this reason, Turkey was forced to move along with the West in the region.

The rivalry between Turkey and Russia on the supply of energy to Western markets has prompted Russia to support the PKK terrorist organization in the eastern part of Turkey's pipeline. Armenia, which has to follow Russia's policy, is also among the countries that support the PKK. In general, after the Justice and Development Party (JDP) came to power, Turkey changed its South Caucasus policy. Armenia was also involved in this policy. Turkey has been trying to solve Armenian policy through Moscow for many years. 
However, since March 2005, the situation has changed. Turkey was already trying to solve Armenian politics through Georgia. Because Turkey saw close ties between Russia and Armenia, it feared that it would adversely affect its policies in the South Caucasus.

Although it will not be able to join the EU anytime soon, Georgia supports Turkey's accession to the EU in order to maintain its independence and territorial integrity. Georgia would be a neighbor to the EU if Turkey became a member of the EU. Georgian President Mikheil Sakashvili said: "Turkey is a country that is rapidly integrating into Europe. This is the shortest way for Georgia to get to Europe. "Turkey has also become a more important economic partner. The Georgian economy has been a natural successor of the Turkish economy." Russia has tried to produce the projects that will ensure energy transportation to the West to cross on its territory. European states and especially, including the USA have found Georgia-Turkey and Iran-Turkey route as an alternative to Russia at power lines preventing the system that gives Russia a great advantage in the political sphere.Because the lack of the direct border of Caspian which has significant oil and gas resources with Turkey, a close border between Turkey and Armenia geographically demands Georgia-Turkey or Iran-Turkey routes to transport Central Asia and Caspian energy routes to the West.The strained relations between Iran and the West reasoned a more positive approach of the West to GeorgiaTurkey routes. As a result, Tbilisi-Ankara cooperation has increased substantially with the creation of BakuTbilisi-Ceyhan pipeline.

From one side, Turkey tries to set a safe power supply system for itself and from the other side, the country efforts to increase geopolitical significance as " a country of energy terminal". The former Minister of Foreign Affairs of Turkey, Ismail Jem expressed that becoming a terminal country is Turkey's new global mission in XXI century.It is essential for Turkey to execute "bridge" function. Only in XXI century, Turkey Transit Corridor wants to become a terminal country from a bridge country that links Europe and Asia trade. Put another way, the main function of Turkey is not to share energy and raw material products from Asia to Europe, it is to become a country that consumes more of these products and exports them with added value. It should be enriched by processing of raw energy material of Turkey, producing and exporting of used energy products(Gurlesel, Vatan newspaper, 03 May 2003)

Georgia saw its problems in its cooperation with the West and in building a democratic system. In this regard, Turkey has played a very important role in the military relationship with NATO beyond its western integration. Georgian President E. Shevardnadze "Georgia is not the southern wing of Russia's strategic region, but the strategic wing of Turkey and NATO, the northern wing extending from Turkey and Israel to Central Asia." Even Georgian President E. Shevardnadze wanted to keep the Russian military units out of the territory of Turkey. This policy will also eliminate Georgia's security concerns with Russia.

After a rupture in 2015, when Turkish fighter jets downed a Russian warplane over Syria, Russia and Turkey have repaired relations. But a Turkish pivot east does not appear imminent. Ankara and Moscow still compete for influence, and their interests still collide, in the South Caucasus(REPORT 250 / EUROPE \& CENTRAL ASIA 28 JUNE 2018). At present, Turkey and Russia have some disagreements about the South Caucasus. The South Caucasus, one of the areas where interests are overlapping, is important for both countries to pass pipelines that are able to meet Europe's energy demand. However, Turkey's extensive trade with Russia and energy relations have partially softened Moscow's approach to Ankara. However, in some cases in the South Caucasus the interests of both countries conflict. Thus, the two countries' approaches to the settlement of ethnic conflicts such as Nagorno-Karabakh, Abkhazia and South Ossetia are different.

\section{The role of Turkey and Georgia in the security of the South Caucasus. Caucasus Stability and Cooperation Agreement}

Security is at the heart of Turkey's South Caucasus policy. In the context of security, the transformation of the South Caucasus into a stable neighbor region is one of Turkey's foreign policy priots. Turkey's main goal was to create an organization in the Caucasus under the control of EU like NATO. The main objective of this organization is to find a more effective solution to the "frozen problems" in the region. To this end, the idea of the "Common Caucasus House" put forward by President of the Republic of Azerbaijan H.Aliyev deserves special attention. President of the Republic of Azerbaijan H.Aliyev: Our most cherished wish is peace in Azerbaijan, the entire Caucasus region and the world. Thus, the peace and stability in the Caucasus may once again attract the attention of the world, but the interests of the great powers have not prevented the realization of this project. 
In 2002, a change in Turkish foreign policy led to a new course called the concept of 'soft power'. As stated by former Turkish Foreign Minister Davutoglu in his book "Strategic Depth", the new Ottoman policy began to form the basis of Turkey's foreign policy. The basis of this policy was the idea of "zero problems with neighbors". Turkey's geographical and historical ties make it difficult to intervene in the events of its early days. Referring to the foreign policy of Turkey, Davutoglu, one of Turkey's foreign policy architects, said, "Turkey bases its policy on aggression and its integration into the region."(http://ak academicperspektif.com.) To this end, in April 2002, the "Trabzon Agreement" was signed between Turkey, Azerbaijan and Georgia in Trabzon. With this agreement, Turkey, Georgia, and Azerbaijan formed triangles in the region, which began to upset Russia and Iran, the neighbors of the region. The Caucasus Stability and Cooperation Platform is a well-intentioned diplomatic move by Turkey, which is concerned about regional security. In this way, Turkey intends to take the initiative in the region as well as to develop favorable relations with its neighbors. However, the complex ethnic and political structure of the Caucasus, as well as the regional geopolitical interests of the United States and Russia show that it is difficult to establish lasting peace and stability in the region. However, Turkey, which is trying to find solutions to problems in the region, will be a great help in establishing regional peace with this platform. This pact was first proposed by the President of the Republic of Azerbaijan Heydar Aliyev at the December 1999 OSCE Summit in Istanbul. All these processes are of particular importance in the development of the peace process in the Caucasus, especially in the South Caucasus. However, this Security Pact, which was created on the initiative of H. Aliyev, should be included in the United States along with the Caucasus and Turkey. This package should be based on the $3+3+2$ model (Azerbaijan, Georgia, Armenia + Russia, Turkey, Iran + US and EU). However, Azerbaijan's proposal was met with some dissatisfaction in Russia, Armenia and Iran(Hasanov, 2005, p 697). Thus, Russia, which is outside of the formation of Russia and regional security system, which considers unacceptable US interference in processes in the region, has not accepted the pact. The main reason for this is that Turkey's involvement with the US in the project meant weakening Russia's position in the Caucasus. Therefore, Russia was trying to create a triangle of Iran and Armenia against the US-TurkeyAzerbaijan-Georgia alliance that could arise in the South Caucasus. Former Turkish President S.Demirel said that during his visit to Tbilisi in January 2000, the idea of reducing the Russian military, first of all, was to create a platform similar to the Southeast European Security Pact on the Balkans. At the suggestion of Demirel, he hoped that this treaty would move ahead of the countries that wanted to build their influence over the countries of the region, thus helping to preserve peace and security in the region. A Stability Pact would have to be established for the Caucasus, similar to the US-led platform in the Balkans. At a joint press conference with President of the Republic of Georgia E. Shvardnadze, the Turkish President S. Demirel said that the platform is not under the control of a country and is an important tool for the settlement of ethnic conflicts in the region(Demirtas, January 17, 2000). Noting that the friendship and cooperation between Turkey and Georgia has reached "unprecedented levels", he highly appreciated the inter-delegation and bilateral talks. In fact, Turkey was trying to create a safe trade corridor for itself through the South Caucasus to Central Asia. For this purpose, first of all, it was necessary to create security in the South Caucasus region.

President of the Republic of Azerbaijan H.Aliyev joined the "Silk Road in the 21st Century" conference in New Haven, Connecticut, on September 21, 2002, emphasizing the need for peace and security in the Caucasus. . Referring to the conflicts in Georgia, the President of Azerbaijan noted that the conflicts in Georgia would be resolved quickly, noting that Azerbaijan supported the territorial integrity of this neighboring state, characterizing the conflicts in Georgia as an internal affair of the country. At the same time, Azerbaijani President H.Aliyev reiterated Azerbaijan's support for Georgia and reiterated the importance of peace and stability in Georgia with the passage of the Baku-Tibilisi-Ceyhan main export pipeline through this area(Aliyev, 2012, p. 109).

Defending the territorial integrity, inviolability, stability, sovereignty and political integrity of Turkey and Georgia, Demirel emphasized the importance of this pact, noting that peace and tranquility in the region are inevitable. The emergence of this pact was seen by the Western press as a response by the United States to Russia through Turkey, at a time when Russia-Georgia relations were strained and Russia adopted a new military declaration. Evaluating this as a "historical fact", Georgian President E.Shvarnadze said that thanks to this pact it would increase attention to the region that crosses Eurasia. 
During the visit of Turkish President Ahmet Sezer to Tbilisi on November 8, 2001, this pact was rediscussed and emphasized that the implementation of the pact would be of great benefit to the countries of the region in terms of peace and security. Since the implementation of this treaty is a threat to destabilize the South Caucasus, Russia has been trying to prevent it by any means, so the realization of the pact is still a dream. With the South Caucasus Security Treaty going, Russia's influence in the region will be weakened, Turkey's influence in the region will increase, and Western powers' ability to interfere in regional politics and security will increase. (Khalilzad, Lesser and Larrabee, 2000, p. 39) . Georgian President E.Shvardnadze said that he wished Turkey to deploy instead of the Russian military, which will be pulled from Abkhazia(www.rferl.org).

Turkey has always been a strong supporter of Georgia and Azerbaijan in consolidating its independence by continuing its security policy in the South Caucasus. To this end, Turkey cooperates in the military sphere with two neighboring countries, meetings are held between the military ministers of the three countries. In April 2002, Turkish President Ahmet Necdat Sezer met with the presidents of Azerbaijan and Georgia in Tbilisi. As a result of the discussions, the interior ministers of the three countries signed an agreement "on joint fight against terrorism and terrorist organizations between the governments of the Republic of Turkey, Azerbaijan and Georgia"(www.mfa.gov.tr).

Georgia seeks to maintain its territorial integrity by developing ties with the US and NATO, but also wants to integrate with the Western world. But Saakashvili, unable to find support from the West in the South Ossetian operation, which he relied on in the United States, was defeated by Russia, and, in effect, wanted to fix the brow. Saakashvili has put Georgian territory in danger. Washington Post writes: Saakashvili says, "If the West is not with us, with whom?" In this case, Georgia is trying to rid its country (M. Saakashvili) of this difficult situation while deteriorating US and EU policies against Russia. But it did not succeed because the US was playing a twofaced game in its policy. He did not want to ruin relations with a state like Russia.

Georgia is one of the regions in which Ankara and Moscow are facing. In August 2008, Russia recognized South Ossetia and Abkhazia as independent states. Turkey supports Georgia's sovereignty and territorial integrity and wanted peace settlement within the framework of international law. Contrary to Moscow, Ankara also supports the Eastern Partnership policy, which aims to strengthen EU economic and social integration among the South Caucasus republics. It should be noted that Turkey's approach to the South Caucasus was well-received by Moscow. Therefore, after the Russian-Georgian conflict in August 2008, Ankara said it wanted to analyze regional issues in such a way that foreign players would be less likely to intervene. The Caucasus Stability and Cooperation Platform, launched under the leadership of Turkey in 2008, has revived to strengthen dialogue in the region(Dmitry, 2014, p 15).

After the war has significantly changed the overall geopolitical balance in the region. Having demonstrated the political will and readiness to use all the means at its disposal in pursuing its staregic objectives, including military force, Russia emerge from the Caucasus conflict (at least for now) as an indisputably dominant power in the region. All the noisy Western rhetoric that had blasted the "Russian aggression" notwithstanding, the West has in practice acquiesed to Russia the role of the predominant geopolitical and security force in the South Caucasus(Torbakov, 2008, p.11). The series if agreements between Moscow and Tbilisi reached with the help of Western mediation only underscore the emergence of a new geopolitical realiti on the ground; although Western actors maintain a presence in the region, they can "act only in the areas approved by Russia and within the limits set by Russia"(Strachota, 2008. p.3).

The AGT cooperation axis has officially established in June 2012 with the Trabzon Declaration, which enhanced the existing partnerships trough the implementation of the a ministerial platform aimed at strengthening political dialogue and promoting mutually relevant projects(www.mfa.gov.tr). Since then, the Forum met yearly and on a rotating base, ${ }^{1}$ focusing its activity on three pillars:

a. Political-diplomatic cooperation- mutual regional and international support

\footnotetext{
${ }^{1}$ After the Trabzon summit the Forum gathered in Batumi in March 2013, in Ganja in February 2014 and in Kars in December 2014
} 
b. Security cooperation- centered on the resolution of protracted conflicts in Nagorno-Karabakh, Abkhazia and South Ossetia on the basis of respect for the sovereugnty, territorial integrityand inviolability of internationally recognized borders of Azerbaijan and Georgia

c. Economic cooperation- designed to increase economic and infrastructural integration in energy and transportation sectors(Frappi, Valigi. 2015, p 32-33).

The AGT axis is the result of a twenty-years long process of trilateral cooperation coherent with the foreign policy views of the three states. This is especially true for Turkeyand Azerbaijan, the two most powerful and politically intertwined elements in the triad. Over the last decade, The Southern Caucasus place in Turkish strategic thinking has been strengthened by the de-securitization process in foreign policy operated by the AKP and by the increased resort to soft power means. But Russia-Turkey competition in the Caucasus adds an extra layer of risk to hostility between Armenia and Azerbaijan. That Moscow and Ankara would work to resolve regional conflicts thus appears unlikely. Nonetheless, their recent rapprochement could serve to calm flashpoints, or at least mitigate the risk of flare-ups(REPORT 250 / EUROPE \& CENTRAL ASIA 28 JUNE 2018).

As we have mentioned, ensuring the independence and territorial integrity of the countries of the region, Azerbaijan and Georgia, is of great importance for Turkey in terms of peace and security in the Caucasus and Central Asia. The US is a foreign actor with the most significant impact on Turkey-Russia relations in the Caucasus. The West is interested in securely moving energy resources in the Caucasus and Central Asia to world markets. Turkey's geostrategic position in the region makes the US more cooperative with it and seeks to exploit the processes in the region for its own benefit. Turkey's participation in the BTC pipeline project is supported by the US, on the other hand, Turkey's intervention in regional conflicts facilitates US regional policy.

The new Georgian Dream government is likely to maintain current relations with Turkey in the economic and security spheres, continue attempts at a balanced relationship wit Russia, and largely stick to the EuroAtlantic direction. However, it is not likely to push as hard for Euro-Atlantic integration as in the past, nor is Turkey going to play a significant role as a vector in this regard(Weiss, Zabanova. December 2016. p 7). All in all, developmens in Turkish-Russian relations will keep affecting Georgia and regional relations.

Although the Georgian leadership wanted to protect Moscow's position in the region by any means, it did not foresee that events would develop until the conflict. Saakashvili's mistakes before the Georgian-Russian conflict that began on August 8, 2008 were an opportunity for Moscow. Although Russia was only able to consolidate its position in the region at the end of the five-day conflict, it had a very negative impact on Moscow's image in the eyes of the international community.

\section{Conclusion}

The fact that Turkey is a country with the potential of an initiative young person allows it to interfere with the processes in the Caucasus. However, the Russian-Georgian conflict in August 2008 once again showed how weak the security in the Caucasus region is. He reiterated the importance of ensuring peace and a secure environment in the future of the region's states. However, a more active policy of the West and Turkey in the region may create new opportunities for the states which are here. The friendship and reconciliation between Armenia and Georgia and Turkey in the South Caucasus will benefit these countries. In spite of some obstacles, Azerbaijan can continue its friendship, fraternity and cooperation indefinitely. Peace in the Caucasus is extremely important for Turkey.

The Caucasus Stability and Cooperation Platform is a well-intentioned diplomatic move by Turkey, which is concerned about regional security. This is an indication of Turkey's intention to take the initiative in the region and to develop good relations with its neighbors. However, the complex ethnic and political structure of the Caucasus, and the regional geopolitical interests of the United States and Russia in confrontation, show that it is difficult to create a stable environment in the region. However, Turkey has tried to show that the hopes of peace in the Caucasus have not been extinguished by implementing this platform. There are still a number of forces that prevent the realization of this platform that Turkey wants to burn for peace in the Caucasus, which is the eastern security. 
The region which receives a growing attention by the global and regional power with each passing day is important for Turkey as well and a great priority at Turkey's foreign policy. After the cold war at Transcaucasia and Black Sea surrounding Turkey, the improvement of significant process appeared. Therefore, Turkey struggling with many international problems has to own its historical heritage and responsibility at the geography of the Black Sea and Transcaucasia and determine its interests and objects at the Black Sea and Transcaucasia again in this context.Turkey is not only the considerable neighbour that can contribute to the development of the economy and the door opening to the West, it is but also the bridge for Georgia to join EU and NATO.The main preventing issue to become a member of NATO for Georgia is Abkhazia and South Ossetia problem. The significant of Georgia for Turkey is the security of energy and transport routes and the same case for Georgia is more strategic. Generally, there are three main reasons of Georgia to have such a warm relation with Turkey;

- The projects about the transportation of Caspian oil to Turkey ports passing through Georgia and including Georgia in these projects,

- Considering Russia as a threat to the independence and territorial integrity of Georgia and a wish to have warm relations with USA and NATO through Turkey to prevent this threat,

- Being in need of Turkey economically as a result of deterioration of relations with Russia

\section{References}

[1.] Brzezinski Zbigniew, Great Chess Board, Istanbul, Sabah Publications, 1998, 2nd edition, United States.

[2.] Bal Idris. Turkish Foreign Policy in the 21st Century, Ankara 2006.

[3.] Mullah and Train's Dmitry. Investments in Russian-Turkish Business Opportunities in a Chalked Area. Turkey 2014.

[4.] Haydar Aliyev. Our independence is eternal. Baku, 2012.

[5.] Hasanov Ali. Contemporary International Relations and Azerbaijan's Foreign Policy. Baku 2005.

[6.] Foreign press in Turkey, RFE / RL Newsline, 13 June 2001 https://www.rferl.org

[7.] Carlo Frappi, Marco Valigi. Patterns for cooperation in the Southern Caucasus area(Azerbaijan,Georgia and Turkey- triangular diplomacy in the shadow of energy strategy). Edited by Farhad Mammadov, Fuad Chiragov. Trilateral Dimension Of Azerbaijan's Foreing Policy. Baku 2015.

[8.] Interview with Georgian Defense Minister Irakli Alasania. The 2013 issue of Turkish Policy Quarterly (TPQ) is www.turkishpolicy.com

[9.] Igor Torbakov, The Georgia Crisis and Russia-Turkey Relations. The Jamestown Foundation. 2008

[10.] Krzysztof Strachota, The Southern Caucasus and Central Asia after the Russia-Georgia war. The Geopolitical Consequences, CEA Commentary 10. 2008

[11.] Ministry of Foreign Affairs of the Turkish Republic www.mfa.gov.tr 30 April 2002

[12.] Levent Shen. Cold War Politics in Turkey after the Cold War. Ankara 2008 s 30.

[13.] Ozcan Alkan Joy. Caucasus Platform "is getting hotter? www.anlayis.net/makale September 2008

[14.] Republic of Turkey. Ministry of Foreign Affairs. Trabzon Declaration Of The Ministers Of Foreign Affairs Of Azerbaijan, Georgia And The Republic Of Turkey, 08 June 2012, Trabzon. www.mfa.gov.tr

[15.] Serkan Demirtash, "Reference to a New Caucasus," Republic, January 17, 2000.

[16.] Turkey-Georgia Relations: Areas of Cooperation, Problems and Solutions. http://ak academicperspektif.com/2013/01/05.

[17.] Zalmay Khalilzad, Ian Lesser and Stephen Larrabee, The Future of Turkish-Western Relations: Toward a Strategic Plan, Santa Monica, CA, RAND, 2000.

[18.] Weiss Andrea, Zabanova Yana. Georgia and Abkhazia caught Turkey and Russia: Turkey's changing with Russia and the West in 2015-2016 and their impact on Georgia and Abkhazia. SSOAR(Open Access Repository) December 2016. www.ssoar.info

[19.] Yanar Sawash. Secret power in the Turkish-Russian relations of the Caucasus. I.G. Culture, Art and Publishing, Istanbul 2002. 
[20.] Russia and Turkey in the Black Sea and the South Caucasus. REPORT 250 / EUROPE \& CENTRAL ASIA 28 JUNE 2018https://www.crisisgroup.org/europe-central-asia/westerneuropemediterranean/turkey 13 December 2016 